\title{
KORONARINE ŠIRDIES LIGA SERGANČIŲJŲ SMEGENŲ POKYČIŲ IVERTINIMAS
}

\author{
Evelina Marija Blažytė ${ }^{1}$, Viltė Gabrielè Samsonè ${ }^{1}$, Daina Krančiukaitė - Butylkinienè $\dot{e}^{2,3}$, \\ Jūratė Dementavičienè $\dot{e}^{4,5}$ \\ ${ }^{1}$ Vilniaus universiteto Medicinos fakultetas, ${ }^{2}$ Lietuvos sveikatos mokslu universiteto \\ Medicinos akademijos Kardiologijos institutas, \\ ${ }^{3}$ Lietuvos sveikatos mokslu universiteto Medicinos akademijos Šeimos medicinos klinika, \\ ${ }^{4}$ Vilniaus universiteto ligonine Santaros klinikos, Radiologijos ir branduolinès medicinos centras, \\ ${ }^{5}$ Vilniaus universiteto Medicinos fakulteto Radiologijos, branduolinès medicinos ir \\ medicinos fizikos katedra
}

Raktažodžiai: intrakranijinių arterijų stenozè, išeminis galvos smegenų insultas, koronarinè širdies liga, miokardo infarktas.

\begin{abstract}
Santrauka
Šiame darbe, analizuodami sergančiųų koronarine širdies liga galvos smegenų magnetinio rezonanso tomografijos tyrimų vaizdus, siekėme nustatyti galvos smegenų kraujagyslinius pakitimus, susijusius su koronarine širdies liga, bei įvertinti gautus rezultatus. Retrospektyvinis tyrimas atliktas Vilniaus universiteto ligonineje Santaros klinikose. Tyrimui atrinkti 33 50-80 m. amžiaus koronarine širdies liga sergantys ir turintys nustatytą širdies nepakankamumo NYHA 3 funkcinę klasę pacientai, kuriems atliktas galvos smegenų magnetinio rezonanso tomografijos tyrimas. Galvos smegenų intrakranijinių kraujagyslių ateroskleroziniai pažeidimai, galvos smegenu involiuciniai pakitimai bei koronarinès širdies ligos pažeidimai buvo nustatyti visiems tirtiems ligoniams, išskiriant dažniausiai pažeidžiamas kraujagysles bei palyginant gautus rezultatus su kitų šalių tyrimų rezultatais. Nustatyta, kad 63,6 proc. tirtų pacientų turi galvos smegenų kraujagyslių pažeidimų, 45,5 proc. iš jų pažeistos 2 ir daugiau kraujagyslių. Dažniausiai pažeistos a. carotis interna dextra (39,4 proc.) ir a. carotis interna sinistra (30,3 proc.) kraujagyslès. Atsižvelgiant ị koronarine širdies liga sergančiųju intrakranijinių kraujagyslių pažeidimų dažnį, svarbu įvertinti ne tik dažniau europiečių populiacijoje pa-
\end{abstract}

sitaikančius ekstrakranijinius pažeidimus, tačiau ir intrakranijinių kraujagyslių aterosklerozinius, okliuzinius pokyčius, kuriuos sąlygoja kompleksiškai pasireiškiantys kardiovaskuliniai reiškiniai.

\section{Ivadas}

Koronarinė širdies liga (KŠL) - tai būklè, kurios metu pažeidžiamos širdies vainikinès arterijos, vystosi ateroskleroziniai pokyčiai ir miokardo išeminiai pakenkimai. Pastaruoju metu vis didesnị gydytojų bendruomenès susirūpinimą kelia širdies ir kraujagyslių ligų, pirmaujančių pasaulyje pagal mirtingumo rodiklius, ankstyvos diagnostikos ir gydymo sprendimų paieškos [1]. Daugumai pacientų, kuriems nustatomi ateroskleroziniai kraujagyslių pakitimai, pirmieji ligos simptomai pasireiškia vẻlai, nes mažos plokštelès nesutrikdo kraujotakos, susidaro kolateralès. Negydoma KŠL gali komplikuotis krūtinès angina bei ūminiu koronariniu sindromu ir mirtimi, todèl itin svarbi ankstyva ligos diagnozè, užkertanti kelią tolimesniems kraujagyslių pažeidimams [2]. Ekstrakranijinių arterijų pažeidimai KŠL sergantiems pacientams vertinami jau seniai. Tuo tarpu informacijos apie KŠL ir intrakranijinių arterijų stenozès ryši labai trūksta. Intrakranijinių arterijų sklerozè susijusi su padidejusia išeminio galvos smegenų insulto (GSI) bei mirties rizika [3]. Išsamesni klinikiniai tyrimai padètų nustatyti šių patologijų ryšį bei tuo pasinaudojant pritaikyti savailaiki gydymą.

Tyrimo tikslas - analizuojant sergančiujjų KŠL galvos smegenų magnetinio rezonanso tomografijos (MRT) tyrimų vaizdus, nustatyti galvos smegenų kraujagyslinius pakitimus, susijusius su KŠL, išskirti dažniausiai pažeidžiamas krauja- 
gysles bei ịvertinus gautus rezultatus juos palyginti su kitu šalių tyrimų rezultatais.

\section{Tyrimo medžiaga ir metodai}

Retrospektyvinis tyrimas 2016-2017 metais atliktas Vilniaus universiteto ligoninès Santaros klinikose. Tyrimui buvo atrinkti 33 KŠL sergantys pacientai, kuriems 2013-2014 metais atlikta galvos smegenų MRT. Atrankos kriterijai KŠL ir ateroskleroze sergantieji pacientai nuo 50 iki $80 \mathrm{~m}$. amžiaus, turintys nustatytą širdies nepakankamumo NYHA 3 funkcinę klasę. Tiriamają grupę sudarė 33,3 proc. $(n=11)$ moterų ir 66,7 proc. $(\mathrm{n}=22)$ vyrų. Amžiaus vidurkis $66,5 \pm 8$ $\mathrm{m}$. Gauti rezultatai buvo analizuoti IBM SPSS programa.

\section{Rezultatai}

Nustatyta, kad 63,6 proc. ( $\mathrm{n}=21 ; 95$ proc. PI 46,7-78,6 proc.) tirtų pacientų turi galvos smegenų kraujagyslių pažeidimų (1 pav.), 45,5 proc. (n=15) iš jų pažeistos 2 ir daugiau kraujagyslių. Dažniausiai pažeistos $a$. carotis interna dextra $(39,4$ proc.; $\mathrm{n}=13)$ ir a carotis interna sinistra (30,3 proc.; $\mathrm{n}=10$ ) kraujagyslès. A. vertebralis pažeidimai nustatyti 36,4 proc. ( $\mathrm{n}=12)$ pacientų (2 pav.). Leukoencefalopatija nustatyta 90,9 proc. $(n=30)$ pacientų. Lyginant pokyčių pasiskirstymą tarp vyrų ir moterų, kraujagyslių pažeidimai nustatyti 59,1 proc. $(\mathrm{n}=13)$ vyrų ir 72,3 proc. $(\mathrm{n}=8)$ moterų. A. carotis interna dextra pažeidimai nustatyti 36,3 proc. $(n=8)$ vyrams

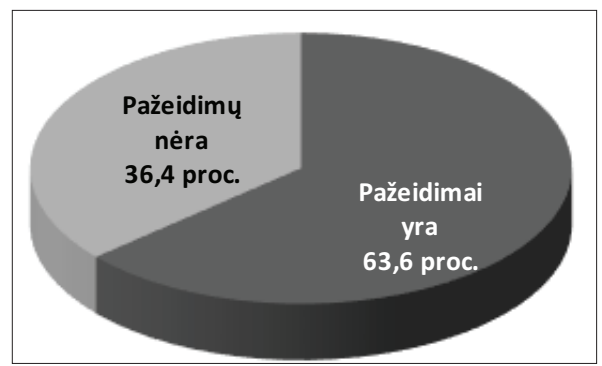

1 pav. Intrakranijinių pažeidimų dažnis tarp koronarine širdies liga sergančiujų pacientų

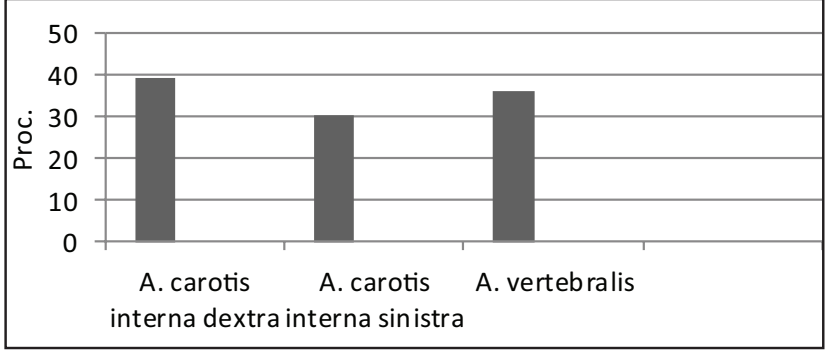

2 pav. Dažniausiai pažeidžiamos intrakranijinès kraujagyslès tarp koronarine širdies liga sergančiujų pacientų ir 45,5 proc. $(\mathrm{n}=5)$ moterims, a. carotis interna sinistra pažeidimai atitinkamai 36,3 proc. $(\mathrm{n}=8)$ ir 18,2 proc. $(\mathrm{n}=2)$. $A$. vertebralis pažeista 36,3 proc. $(\mathrm{n}=8)$ vyrams ir 27,3 proc. $(n=3)$ moterims (3 pav.). Leukoencefalopatija nustatyta 86,3 proc. $(n=19)$ bei 100 proc. $(n=11)$ moterų.

\section{Diskusija}

Tiriant intrakranijinę kraujotaką pastebima, kad aterosklerozė pasireiškia dviem skirtingais keliais. Vakarų populiacijoms, kurioms labiau būdinga ekstrakranijinè ir sisteminè aterosklerozé, intrakranijinių kraujagyslių pažeidimai yra

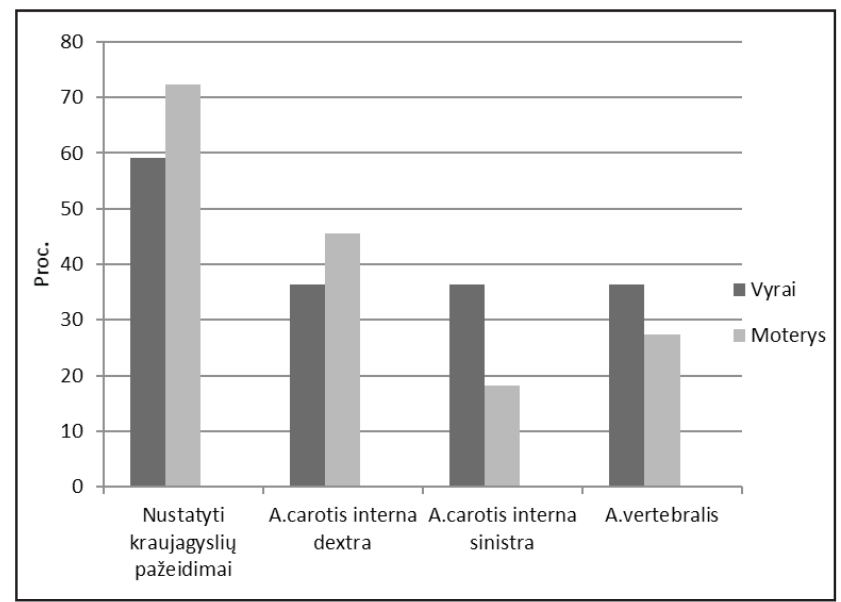

3 pav. Dažniausiai pažeistų arterijų paplitimas tarp vyrų ir moterų

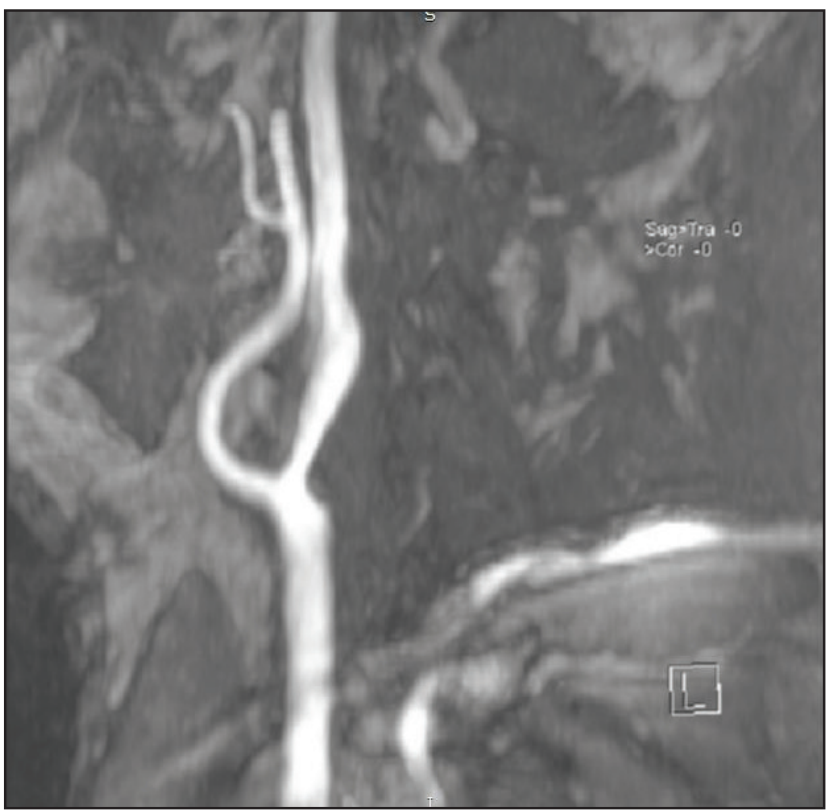

4 pav. A. carotis interna stenozè 
retesni. Tuo tarpu Azijos bei Afrikos šalių gyventojams, kuriems būdingesnè izoliuota intrakranijinių arterijų liga, dažniau pastebimi GSI atvejai nei ekstrakranijinių kraujagyslių ateroskleroziniai pažeidimai [4]. Tai lėmė plačius ekstrakranijinių kraujagyslių pažeidimų tyrimus europiečių populiacijose, nors pastaruoju metu suprantama, kad intrakranijinių kraujagyslių pokyčiai yra ne mažiau svarbūs [2]. Intrakranijinių kraujagyslių tyrimai, kurie atliekami norint išsiaiškinti patologinius pokyčius, yra itin sudètingi dèl lavonų tyrimų apribojimų ir tiriamosios medžiagos trūkumo, taigi, diagnostika gyviems pacientams atliekama naudojantis MRT prietaisais. Dauguma šiuo metu mokslo literatūroje publikuotų tyrimų, kuriuose tiriama intrakranijinių kraujagyslių būklè, atliekami Azijos valstybėse. Tačiau intrakranijinè aterosklerozė nèra pakankamai išstudijuota, todèl vis dar sunku nustatyti GSI riziką patvirtinančius biomarkerius bei parinkti gydymo strategijas [4].

Šiame tyrime nustatėme, jog tarp KŠL sergančiujų pacientų vyravo a. carotis interna dextra bei $a$. carotis interna sinistra kraujagyslių pažeidimai. Šiuo metu mažai žinoma apie besimptomius intrakranijinių kraujagyslių pažeidimus, kurie stebimi tarp KŠL sergančiujjų pacientų, tačiau teigiama, jog šie ateroskleroziniai pokyčiai yra glaudžiai susiję su arterijų standumu [5]. Jo nustatymui svarbus MRT, kurio vaizdus nagrinèjome šiame darbe ir turejome galimybę ịvertinti vizualius arterijų sienelių pokyčius (4 pav). Kumamoto universiteto (Japonija) mokslininkai tyre subklinikinių intrakranijinių arterijų pažeidimų santykị su arterijų sienelių standumu bei KŠL sergančiųų pacientų, kuriems nebuvo nustatyti smegenų arterijų pokyčiai, prognozę. MRT prietaisu ištyrus 149 pacientus, paaiškejjo, jog turintiems intrakranijinius kraujagyslių pažeidimus pacientams pastebimas reikšmingai didesnis žasto - kulkšnies impulso bangos greitis, kuris parodo arterijų standumą. Šiai pacientų grupei pastebėti dažnesni kardiovaskuliniai susirgimai bei blogesnè ligos prognozè nei pacientams be intrakranijinių kraujagysliu pažeidimų [6]. Tai parodo, kad intrakranijinių kraujagyslių pažeidimų vertinimas KŠL sergantiems pacientams gali turèti prognostinę vertę.

KŠL taip pat gali būti susijusi su protine veikla bei nulemti nedideli pažinimo sutrikimą. Galvos smegenų MRT tyrimo metu, matuodami smegenų tūrių pokyčius, Melburno (Australija) mokslininkai nustatè, jog smegenų tūris gali būti laikomas objektyviu biologiniu žymeniu pažinimo sutrikimo nustatymui. Minètame tyrime buvo nustatytas ryšys tarp smegenų tūrio sumažèjimo ir KŠL. Pacientams, turintiems pažinimo sutrikimą, rasti didesni vainikinių širdies arterijų stenoziniai pokyčiai koreliavo su mažesniu pilkosios sme- genų medžiagos kiekiu smegenų regionuose, atsakinguose už kognityvinę funkciją [7]. Mūsų atliktame tyrime kognityvinio pažinimo sutrikimai nebuvo nagrinèti, tačiau involiuciniai smegenų pakitimai buvo pastebimi tirtų pacientų grupejje.

Autosominiu dominantiniu būdu paveldima smegenų arteriopatija kartu su požieviniais infarktais bei leukoencefalopatija yra dažniausia kraujotakos sutrikimų sąlygojama demencijos priežastis ir yra siejama su NOTCH3 geno mutacijomis [8]. NOTCH3 genas koduoja transmembranini baltymą, kurio raiška aptikta kraujagyslių lygiujų raumenų ląstelių citoplazminiame tinkle [9]. Neurologinè šio sindromo išraiška yra aiškiai charakterizuota, tačiau pastebima, kad ji taip pat glaudžiai susijusi ir su KŠL. Pensilvanijos ligoninès gydytojai aprašè 45 metų pacientę, kuriai kartu su minètuoju sindromu pasireiškè nestabili krūtinès angina, buvo nustatyta KŠL [10]. Mūsų tyrime net 90,9 proc. pacientų buvo stebima leukoencefalopatija, dažniau pasitaikiusi tarp moterų. Manome, kad šio faktoriaus svarba yra didelè ir turètų būti nepamiršta tiriant KŠL bei miokardo infarkto (MI) sąsajas ir galimas prognozes.

KŠL santykis su besimptomiais miego arterijų bei intrakranijinių arterijų pažeidimais buvo tirtas ir Japonijoje. Tyrimo metu $67 \mathrm{KŠL}$ sergantiems pacientams buvo atliktas galvos smegenų MRT tyrimas. Didesnè nei 25 proc. intrakranijinių arterijų stenozė nustatyta 16,4 proc. tirtųu pacientų. Ekstrakranijinių miego arterijų stenozių dažnis $(22,4$ proc.) ir vainikinių arterijų ateroskleroziniai pažeidimai koreliavo tarpusavyje. Tyrimas parodè, jog japonams, segantiems KŠL, gana dažnai nustatomi besimptomiai miego ir intrakranijinių arterijų stenoziniai pažeidimai, tačiau stenozès laipsnis yra gana mažas [11]. Korejjoje atliktame tyrime nustatyta, kad pacientai, turintys koronarinių arterijų stenozę bei KŠL, dažniau nei nesergantieji patirdavo intrakranijinių arterijų stenozės sukeltą GSI (61,1 proc.) [12]. Intrakranijinių arterijų tyrimas ir savalaikis gydymas tokiems pacientams yra ypač svarbus. Tuo tarpu Calvet D. ir kt. (Prancūzija) atliktame tyrime tirti 274 pacientai, patyrę išemini insultą arba praeinanti smegenų išemijos priepuolį, prieš tai netureję KŠL anamnezès. Nustatyta, kad penktadalis iš šių pacientų jau turẻjo asimptominę KŠL (50 proc. ar daugiau) [13]. Atsižvelgiant ị šiuos rezultatus, nustačius GSI diagnozę, tikslinga atlikti tyrimus širdies būklei ịvertinti.

Valld'Hebron universiteto ligonineje (Ispanija) buvo atliktas tyrimas, kurio metu išsiaiškinta, jog 52 proc. pacientų, sirgusių MI dèl intrakranijinių arterijų stenozės (IAS), buvo stebima sutrikusi miokardo perfuzija [14]. Panašus tyrimas buvo atliktas ir Kioto universitete (Japonija). Jo metu nustatyta, jog IAS yra tiesiogiai susijusi su KŠL ir yra svarbi GSI 
prognozavimui [15]. Vienerių metų trukmės studijoje Kaire (Egiptas), tiriant egiptiečių populiaciją, tarp pacientų, sergančių KŠL, nustatytas IAS dažnis 11,9 proc. [16]. Taigi, galima teigti, jog intrakranijinių kraujagyslių pažeidimų vertinimas gali būti vienas iš KŠL sergančių ligonių prognozès kriterijų.

Šių tyrimų tikslas buvo išryškinti KŠL, MI ir GSI koreliacijos svarbą. Atsižvelgiant ị gautus rezultatus, akivaizdu, kad šios būklès negali būti atskirtos. Skirtingų metodologijų, tiriamuju grupės dydžio, genetiniai bei aplinkos faktoriai gali paaiškinti statistikos neatitikimus, pateikiamus literatūroje. Vis dèlto sutinkama, kad KŠL sergantiems pacientams reikia įtarti intrakranijinių arterijų pokyčius ir ịvertinti išeminio GSI riziką. Taip pat ir pacientams, patyrusiems išeminị GSI, negalima atmesti KŠL galimybès, net jei pacientas neturi panašių skundų. Šios būklès privalo būti vertinamos remiantis bendrais kriterijais, atsižvelgiant ị šalutiniua veiksnius, kurių eiga gali būti abipusè.

\section{Išvados}

Pastaraji dešimtmetị didelio dėmesio susilaukianti koronarinė širdies liga yra tiriama atsižvelgiant ị kliniškai reikšmingus faktorius, skatinančius ligos progresavimą bei lemiančius šalutinių ligų atsiradimą. Vieni iš svarbiausių pokyčių sergant koronarine širdies liga yra galvos smegenų ateroskleroziniai pažeidimai. Nors europiečių populiacijai labiau būdingi ekstrakranijinių kraujagyslių pokyčiai dèl koronarinès širdies ligos, svarbu įžvelgti ir intrakranijinių kraujagyslių pažeidimų tendencijas, nes jų vertinimas bei matavimo reikšmės gali tapti potencialiais ligos baigčiu vertinimo būdais klinikineje praktikoje.

\section{Literatūra}

1. WHO | The top 10 causes of death. WHO; 2017.

2. Lorenzo C, Nicastro I, Barletta V, Bello V, Fabiani I. Sudden cardiac death: A review focused on cardiovascular imaging. J Cardiovasc Echogr 2014;24(2):41. https://doi.org/10.4103/2211-4122.135611

3. Conforto AB, Leite Cda C, Nomura CH, Bor-Seng-Shu E, Santos $\mathrm{RD}$. Is there a consistent association between coronary heart disease and ischemic stroke caused by intracranial atherosclerosis? Arq Neuropsiquiatr 2013;71(5):320-6.

https://doi.org/10.1590/0004-282X20130028

4. Chen XY, Fisher M. Pathological Characteristics. Front Neurol Neurosci 2016;40:21-33.

https://doi.org/10.1159/000448267

5. Fatic N, Jaffer U, Ivana S, Gordana GV, Markovic D, Kostic D. et al. Bilateral internal carotid arteries occlusion, external carotid arteries stenosis and vertebral arteries kinking- may it be asymptomatic? Ann Vasc Surg 2017;S0890-5096(16):31344-9.
6. Tabata N, Sueta D, Yamashita T, Utsunomiya D, Arima Y, Yamamoto E. et al. Relationship between asymptomatic intra-cranial lesions and brachial-ankle pulse wave velocity in coronary artery disease patients without stroke. Hypertens Res 2017;40(4):392-8.

https://doi.org/10.1038/hr.2016.159

7. Barekatain M, Askarpour H, Zahedian F, Walterfang M, Velakoulis D, Maracy MR, et al. The relationship between regional brain volumes and the extent of coronary artery disease in mild cognitive impairment. J Res Med Sci 2014;19(8):739-45.

8. Liao YC, Hsiao CT, Fuh JL, Chern CM, Lee WJ, Guo YC. et al. Characterization of CADASIL among the Han Chinese in Taiwan: distinct genotypic and phenotypic profiles. Brusgaard K, editor. PLoS One 2015;26;10(8):e0136501. https://doi.org/10.1371/journal.pone.0136501

9. Li X, Zhang X, Leathers R, Makino A, Huang C, Parsa P, et al. Notch3 signaling promotes the development of pulmonary arterial hypertension. Nat Med 2009;15(11):1289-97. https://doi.org/10.1038/nm.2021

10. Rubin CB, Hahn V, Kobayashi T, Litwack A. A Report of accelerated coronary artery disease associated with cerebral autosomal dominant arteriopathy with subcortical infarcts and leukoencephalopathy. Case Reports Cardiol 2015;2015:167513 https://doi.org/10.1155/2015/167513

11. Uehara T, Tabuchi M, Hayashi T, Kurogane H, Yamadori A. Asymptomatic occlusive lesions of carotid and intracranial arteries in Japanese patients with ischemic heart disease: evaluation by brain magnetic resonance angiography. Stroke 1996;27(3):393-7.

https://doi.org/10.1161/01.STR.27.3.393

12. Seo WK, Yong HS, Koh SB, Suh S, Kim JH, Yu SW. et al. Correlation of coronary artery atherosclerosis with atherosclerosis of the intracranial cerebral artery and the extracranial carotid artery. Eur Neurol 2008;59(6):292-8.

https://doi.org/10.1159/000121418

13. Calvet D, Touze E, Varenne O, Sablayrolles JL, Weber S, Mas JL. Prevalence of asymptomatic coronary artery disease in ischemic stroke patients: The PRECORIS Study. Circulation 2010;121(14):1623-9. https://doi.org/10.1161/CIRCULATIONAHA.109.906958

14. Arenillas JF, Candell-Riera J, Romero-Farina G, Molina CA, Chacon P, Aguade-Bruix S. et al. Silent myocardial ischemia in patients with symptomatic intracranial atherosclerosis: associated factors. Stroke 2005;36(6):1201-6.

https://doi.org/10.1161/01.STR.0000166045.12976.af

15. Hoshino A, Nakamura T, Enomoto S, Kawahito H, Kurata H, Nakahara $\mathrm{Y}$ et al. Clinical utility of evaluating intracranial artery stenosis and silent brain infarction to predict the presence of subclinical coronary artery disease in ischemic stroke patients. Intern Med 2008;47(20):1775-81.

https://doi.org/10.2169/internalmedicine.47.1314

16. Abd-Allah F, Heshmat Kassem H, Hashad A, Shamloul RM, 
Zaki A. Prevalence of intracranial atherosclerosis among patients with coronary artery disease: A 1-year hospital-based study. Eur Neurol 2014;71(5-6):326-30.

https://doi.org/10.1159/000358055

\section{CEREBRAL VASCULAR LESIONS ASSOCIATED WITH CORONARY HEART DISEASE}

E. M. Blažytė, V. G. Samsonė, D. Krančiukaitè-Butylkinienė, J. Dementavičienè

Key words: intracranial artery stenosis, ischemic stroke, coronary artery disease, myocardial infarction.

Summary

In this study, we analyzed patients with coronary heart disease who underwent brain magnetic resonance tomography in order to determine cerebral vascular lesions associated with coronary heart disease and to evaluate the results. Retrospective study was carried out at Vilnius University Hospital, Santaros clinic's. A total of 33 patients aged 50 to 80 years, suffering from coronary heart disease and heart failure (NYHA functional class 3) who underwent brain magnetic resonance tomography were selected for this study. Intracranial atherosclerotic lesions and involutional brain changes have been identified in all studied patients, highlighting the most affected intracranial arteries. These results have been compared with studies conducted in other countries. We found that 63.6 percent of studied patients had cerebral vascular lesions, 45.5 percent of patients had two or more affected arteries. The most commonly affected were a. carotis interna dextra (39.4 percent) and a. carotis interna sinistra (30.3 percent). Intracranial atherosclerosis and vascular lesions were found to be less common in European populations compared to Asians, however more research and clinical trials are needed to answer whether aggressive treatment of coronary artery disease can decrease the risk of ischemic stroke caused by intracranial atherosclerosis.

Correspondence to: emblazyte@gmail.com

Gauta 2017-05-16 